\title{
Analisis Lintas Sifat Morfo-Agronomis dan Fisiologis Jagung (Zea mays L.)
}

\author{
Annisa Malik*, Farit M Afendi*, Akbar Rizki*, Sutoro** \\ * Departemen Statistika Institut Pertanian Bogor \\ ${ }^{* *} \mathrm{BB}$ Biogen
}

\begin{abstract}
Abstrak-Jagung (Zea mays L.) merupakan komoditi pangan terpenting ketiga setelah gandum dan padi berdasarkan bahan makanan pokok dunia, serta menempati peringkat kedua setelah padi berdasarkan bahan makanan pokok di Indonesia. Varietas jagung unggul yang memiliki produktivitas tinggi sangat diperlukan untuk memenuhi kebutuhan pangan, pakan, dan industri. Varietas tersebut dapat diperoleh melalui program pemuliaan tanaman dengan memanfaatkan sumber gen yang mampu menghasilkan karakter tanaman yang baik. Sumber gen dapat diperoleh dari plasma nutfah atau varietas lokal yang ada. Karakter tanaman yang dapat menunjang produktivitas tanaman dapat digunakan sebagai indikator pada proses seleksi dalam pemuliaan tanaman jagung. Hal tersebut dapat dilakukan melalui karakterisasi sifat morfo-agronomis dan fisiologis setiap varietas jagung, selanjutnya menentukan karakter-karakter yang menunjang produktivitas tanaman jagung secara langsung maupun tidak langsung. Pengaruh langsung dan tidak langsung suatu karakter tanaman terhadap produktivitas tanaman diidentifikasi melalui analisis lintas. Hasil penelitian menunjukkan bahwa kriteria seleksi yang efektif untuk meningkatkan berat biji jagung secara langsung adalah luas daun. Sedangkan kriteria seleksi yang efektif untuk meningkatkan berat brangkasan jagung secara langsung adalah umur keluar bunga betina. Sementara kriteria seleksi yang efektif untuk meningkatkan berat biji dan berat brangkasan jagung secara tidak langsung adalah tinggi tanaman melalui laju pengisian biji.
\end{abstract}

Kata kunci-analisis lintas; karakter tanaman; jagung;

\section{Pendahuluan}

\section{A. Latar Belakang}

Menurut Purwono dan Hartono (2008), tanaman jagung (Zea mays L.) merupakan komoditi pangan ketiga terpenting setelah gandum dan padi berdasarkan bahan pokok makanan dunia. Sedangkan berdasarkan bahan makanan pokok di Indonesia, jagung menempati posisi kedua setelah padi. Masyarakat Indonesia sering memanfaatkan jagung untuk kebutuhan pangan dan pakan ternak. Selain itu, jagung juga dimanfaatkan sebagai penunjang industri minuman, kimia, dan farmasi. Oleh karena itu, produktivitas dan mutu jagung perlu ditingkatkan agar varietas jagung unggul dapat memenuhi semua kebutuhan baik dari segi pangan, pakan, maupun industri.

Pemuliaan tanaman merupakan salah satu cara untuk meningkatkan daya hasil jagung sehingga menghasilkan varietas jagung unggul. Varietas jagung unggul dapat diperoleh dengan melakukan proses karakterisasi dan seleksi. Karakterisasi dilakukan untuk mengetahui sifat tanaman dari setiap varietas. Sedangkan seleksi dilakukan untuk memilih tanaman yang sifat-sifatnya mempengaruhi produktivitas tanaman jagung terkait pemanfaatannya sebagai bahan pangan, pakan, dan industri. Pemanfaatan tanaman jagung untuk bahan pangan lebih terfokus pada berat biji jagung. Sedangkan pemanfaatan tanaman jagung untuk bahan pakan dan industri fokus pada berat brangkasan (biomassa) jagung. Ciri-ciri varietas jagung unggul yaitu hasil biji persatuan luas tinggi, efisien terhadap pemupukan, toleran terhadap penyakit dan hama, beradaptasi baik pada berbagai lingkungan, tegap dan tahan rebah, jumlah daun hijau tinggi saat panen, serta umur panen relatif singkat (Suprapto (2005)).

Salah satu analisis yang dapat digunakan untuk mengetahui kekuatan hubungan antar peubah adalah analisis lintas. Analisis lintas merupakan pengembangan langsung bentuk regresi berganda dengan tujuan untuk memberikan estimasi tingkat kepentingan dan signifikasi hubungan sebab akibat hipotetikal (dengan menggunakan korelasi) dalam seperangkat peubah. Analisis ini mampu memberikan informasi mengenai pengaruh peubah bebas 
(eksogen) terhadap peubah tak bebas (endogen) tidak hanya secara langsung, tetapi juga secara tidak langsung. Analisis lintas unggul ketika permasalahan yang dihadapi adalah model dengan peubah eksogen tidak hanya mempengaruhi peubah endogen, namun juga mempengaruhi peubah eksogen lainnya (Dillon and Goldstein (1984)). Asadi dan Woerjono (2004) menyatakan bahwa melalui analisis lintas dapat diketahui pengaruh langsung dan tidak langsung antar peubah-peubah eksogen dengan peubah endogen. Hal tersebut akan lebih memudahkan pemulia tanaman dalam melakukan proses seleksi tanaman, serta sebagai landasan dalam perbaikan tanaman.

Rahmawati (2012) menyatakan bahwa sifat agronomis tanaman jagung dapat digunakan sebagai karakter penyeleksi guna mendapatkan tanaman jagung berdaya hasil tinggi. Sifat agronomis yang paling efektif mempengaruhi produktivitas tanaman jagung secara langsung adalah jumlah biji per tongkol, sedangkan secara tidak langsung adalah panjang tongkol melalui jumlah biji per tongkol. Pada penelitian ini, sifat morfo-agronomis dan fisiologis tanaman jagung akan dimanfaatkan untuk mengetahui sifat yang efektif mempengaruhi produktivitas tanaman jagung baik secara langsung maupun tidak langsung. Sifat-sifat tersebut dibagi menjadi tiga kriteria yaitu sifat tanaman jagung fase pra panen (pembungaan), sifat tanaman jagung fase pasca panen, dan hasil akhir tanaman jagung. Hasil dari penelitian ini diharapkan mampu mengidentifikasi sifat tanaman jagung fase pra panen yang berpengaruh efektif terhadap produktivitas tanaman jagung. Sehingga lebih memudahkan para pemulia tanaman untuk menyeleksi tanaman jagung unggul sejak dini.

\section{B. Tujuan}

Tujuan dari penelitian ini adalah menerapkan analisis lintas guna mengetahui peubah-peubah yang berpengaruh langsung dan tidak langsung terhadap produktivitas jagung sehingga didapat varietas jagung unggul.

\section{METODOLOGI}

\section{A. Data}

Data yang digunakan dalam penelitian ini adalah data sekunder hasil penelitian BB BIOGEN tahun
2016 di Kebun Percobaan Cikeumeuh Bogor. Rancangan penelitian yang digunakan adalah rancangan acak kelompok (RAK) dengan 3 ulangan, 50 varietas jagung sebagai perlakuan, serta 20 respon yang merupakan sifat morfo-agronomis dan fisiologis jagung. Peubah-peubah yang diamati dari setiap varietas jagung tersaji pada Tabel I.

Berdasarkan Tabel I, peubah $X_{1}-X_{20}$ merupakan peubah eksogen, sedangkan peubah $Y_{1}$ dan $Y_{2}$ merupakan peubah endogen. Peubah $X_{1}-X_{7}$ dan $X_{15}-X_{19}$ merupakan sifat morfo-agronomis tanaman jagung, sedangkan peubah $X_{8}-X_{14}$ serta $X_{20}$ merupakan sifat fisiologis tanaman jagung. Peubah-peubah tersebut didapat dari proses karakterisasi yang dilakukan pada masing-masing varietas tanaman jagung.

Tabel I

DAFTAR PEUBAH YANG DIGUNAKAN

\begin{tabular}{|c|c|c|c|}
\hline Peubah & Keterangan & Peubah & Keterangan \\
\hline$Y_{1}$ & $\begin{array}{l}\text { berat biji per } 60 \\
\text { tanaman (gram) }\end{array}$ & $X_{10}$ & $\begin{array}{l}\text { umur keluar bunga } \\
\text { betina (hari) }\end{array}$ \\
\hline$Y_{2}$ & $\begin{array}{l}\text { berat brangkasan } \\
\text { (biomass) }(\mathrm{gram})\end{array}$ & $X_{11}$ & umur masak (hari) \\
\hline$X_{1}$ & $\begin{array}{l}\text { panjang tongkol } \\
(\mathrm{cm})\end{array}$ & $X_{12}$ & $\begin{array}{l}\text { jumlah satuan } \\
\text { panas (heat unit) } \\
\text { waktu keluar bunga } \\
\text { jantan }\end{array}$ \\
\hline$X_{2}$ & $\begin{array}{l}\text { diameter tongkol } \\
(\mathrm{cm})\end{array}$ & $X_{13}$ & $\begin{array}{l}\text { jumlah satuan } \\
\text { panas (heat unit) } \\
\text { waktu keluar bunga } \\
\text { betina }\end{array}$ \\
\hline$X_{3}$ & jumlah baris & $X_{14}$ & $\begin{array}{l}\text { jumlah satuan } \\
\text { panas (heat unit) } \\
\text { waktu masak }\end{array}$ \\
\hline$X_{4}$ & $\begin{array}{l}\text { jumlah biji per } \\
\text { tongkol }\end{array}$ & $X_{15}$ & $\begin{array}{l}\text { tinggi tanaman } \\
(\mathrm{cm})\end{array}$ \\
\hline$X_{5}$ & $\begin{array}{l}\text { berat biji per } \\
\text { tongkol (gram) }\end{array}$ & $X_{16}$ & $\begin{array}{l}\text { jumlah daun hijau } \\
\text { saat panen }\end{array}$ \\
\hline$X_{6}$ & $\begin{array}{l}\text { berat } \begin{array}{l}\text { tongkol } \\
\text { (gram) }\end{array} \\
\end{array}$ & $X_{17}$ & $\begin{array}{l}\text { jumlah daun hijau } \\
\text { saat pembungaan } \\
\text { (maksimum) }\end{array}$ \\
\hline$X_{7}$ & $\begin{array}{l}\begin{array}{l}\text { berat } \\
\text { (gram) }\end{array} \\
200 \quad \text { biji }\end{array}$ & $X_{18}$ & $\begin{array}{l}\text { tinggi keberadaan } \\
\text { tongkol }(\mathrm{cm})\end{array}$ \\
\hline$X_{8}$ & $\begin{array}{l}\text { laju pengisian biji } \\
\text { (gram/hari) }\end{array}$ & $X_{19}$ & $\begin{array}{l}\text { luas daun } \\
\left(\mathrm{cm}^{2} / \text { tanaman }\right)\end{array}$ \\
\hline$X_{9}$ & $\begin{array}{l}\text { umur keluar bunga } \\
\text { jantan (hari) }\end{array}$ & $X_{20}$ & $\begin{array}{l}\text { efisiensi daun } \\
\left(\mathrm{gram} / \mathrm{cm}^{2}\right)\end{array}$ \\
\hline
\end{tabular}

\section{B. Metode}

Tahapan metode pada penelitian ini adalah

1) Eksplorasi data 
a) Menghitung nilai korelasi antara peubah endogen dengan eksogen dan nilai korelasi antar peubah eksogen dengan menggunakan rumus Product Moment Coefficient dari Karl Pearson :

$$
r=\frac{N \Sigma X Y-(\Sigma X)(\Sigma Y)}{\sqrt{\left[N \Sigma X^{2}-(\Sigma X)^{2}\right]\left[N \Sigma Y^{2}-(\Sigma Y)^{2}\right]}}
$$

hasil dari perhitungan tersebut kemudian disajikan dalam bentuk matriks.

b) Menghitung koefisien keragaman (KK) dari setiap peubah yang digunakan yaitu 20 karakter tanaman jagung. Peluang untuk menemukan karakter terbaik dari setiap peubah lebih besar apabila koefisien keragaman dari peubah tersebut tinggi. Rumus koefisien keragaman sebagai berikut

$$
K K_{i}=\frac{s_{i}}{\bar{x}_{i}}
$$

keterangan

$$
\begin{array}{ll}
i & =1,2, \ldots, 20 \\
K K_{i} & =\text { koefisien keragaman peubah ke-i } \\
s_{i} & =\text { simpangan baku peubah ke-i } \\
\bar{x}_{i} & =\text { nilai rata-rata peubah ke-i }
\end{array}
$$

c) Membuat histogram sebaran frekuensi data dengan cara membagi data menjadi lima kelompok selang yaitu
i) $x_{i}<\bar{x}-\frac{3}{2} s$
ii) $\bar{x}-\frac{3}{2} s \leq x_{i}<\bar{x}-\frac{1}{2} s$
iii) $\bar{x}-\frac{1}{2} s \leq x_{i}<\bar{x}+\frac{1}{2} s$
iv) $\bar{x}+\frac{1}{2} s \leq x_{i}<\bar{x}+\frac{3}{2} s$
v) $x_{i} \geq \bar{x}+\frac{3}{2} s$

2) Analisis lintas

a) Memeriksa asumsi yang mendasari analisis lintas yaitu asumsi normalitas, linearitas dan keaditifan hubungan antar peubah di dalam model, sisaan tidak saling berkorelasi, serta hubungan dalam model hanya berupa hubungan kausal satu arah (rekursif) (Dillon and Goldstein (1984)).

b) Melakukan identifikasi dan membangun model awal atau spesifikasi model dengan membuat diagram lintas berdasarkan teori, hasil penelitian sebelumnya, atau pendapat ahli di bidang pertanian. Model awal yang digunakan pada penelitian ini tersaji pada sub bab Model Lintas.

c) Melakukan pendugaan koefisien lintas dari model awal yaitu dengan menghitung nilai korelasi sama seperti pada analisis statistika deskriptif. Hasil perhitungan tersebut kemudian disusun menjadi vektor korelasi peubah endogen dan peubah eksogen serta matriks korelasi antar peubah eksogen :

$$
\begin{aligned}
r_{X Y}=\left(\begin{array}{r}
r_{X_{1} Y} \\
r_{X_{2} Y} \\
\vdots \\
r_{X_{20} Y}
\end{array}\right) \\
R=\left(\begin{array}{rrrr}
1 & r_{X_{1} X_{2}} & \ldots & r_{X_{1} X_{20}} \\
r_{X_{2} X_{1}} & 1 & \ldots & r_{X_{2} X_{20}} \\
\vdots & \vdots & 1 & \vdots \\
r_{X_{20} X_{1}} & r_{X_{20} X_{2}} & \ldots & 1
\end{array}\right)
\end{aligned}
$$

Kemudian hitung matriks invers korelasi antar peubah eksogen $\left(R^{-1}\right)$. Nilai koefisien lintas didapatkan dari perkalian dari $R^{-1}$ dan $r_{X Y}$.

d) Melakukan pengujian koefisien lintas dengan menggunakan uji t. Koefisien yang tidak signifikan akan dihilangkan dari model.

e) Menghitung nilai determinasi umum dari model lintas awal dengan rumus :

$$
M_{i}=1-\left(1-R_{1}^{2}\right)\left(1-R_{2}^{2}\right) \ldots\left(1-R_{m}^{2}\right)
$$

f) Membuat diagram lintas baru dari model lintas alternatif yang didapat setelah melakukan pengujian koefisien lintas dari model awal.

g) Ulangi langkah c-e hingga semua peubah eksogen berpengaruh secara signifikan terhadap peubah endogen.

h) Menguji kebaikan model antara model awal (model I) dan model alternatif (model II).

i) Menghitung nilai pengaruh total dari peubah-peubah yang terdapat pada model 
terbaik. Pengaruh total adalah hasil penjumlahan pengaruh langsung dan pengaruh tidak langsung dari peubah eksogen terhadap peubah endogen.

j) Interpretasi hasil.

\section{Model Lintas}

Model lintas awal (Gambar 1) dibagi menjadi dua tahap. Tahap pertama yaitu meneliti hubungan karakter tanaman pada fase pra panen (pembungaan) (peubah eksogen) dengan karakter tanaman pada fase pasca panen (peubah endogen). Sedangkan tahap kedua meneliti hubungan karakter tanaman pada fase pasca panen (peubah eksogen) dengan hasil akhir tanaman jagung yang berupa berat biji dan berat brangkasan jagung (peubah endogen).

Pembagian tahap lintasan bertujuan untuk mengetahui karakter tanaman pada fase pra panen yang berpengaruh terhadap produktivitas tanaman jagung. Hal tersebut akan memudahkan pemulia tanaman dalam menyeleksi tanaman jagung unggul pada fase pra panen. Jadi, proses seleksi tidak perlu dilakukan setelah tanaman jagung dipanen karena sudah terwakili oleh seleksi pada saat fase pra panen.

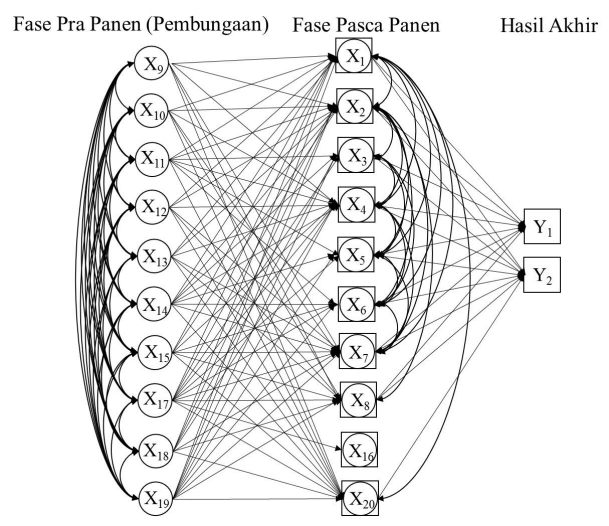

Gambar 1. Diagram lintas model awal

\section{HASIL DAN PEMBAHASAN}

\section{A. Statistika Deskriptif}

Analisis statistika deskriptif pada penelitian ini berguna untuk mengetahui statistik data, ukuran yang digunakan adalah korelasi antar peubah dan koefisien keragaman dari setiap peubah (Indriantoro (2002)). Berdasarkan matriks korelasi, terlihat bahwa semua peubah eksogen memiliki hubungan yang positif terhadap peubah endogen berat biji
$\left(Y_{1}\right)$. Hal tersebut berarti hubungan antara peubah eksogen dan peubah endogen searah. Sedangkan pada peubah endogen berat brangkasan $\left(Y_{2}\right)$ hampir semua peubah eksogen memiliki hubungan yang searah, kecuali peubah efisiensi daun $\left(X_{20}\right)$. Nilai korelasi antara efisiensi daun $\left(X_{20}\right)$ dan berat brangkasan $\left(Y_{2}\right)$ sebesar -0,379 yang berarti efisiensi daun $\left(X_{20}\right)$ memiliki hubungan berbanding terbalik dengan berat brangkasan $\left(Y_{2}\right)$. Hal ini disebabkan oleh besarnya alokasi fotosintat yang diberikan ke bagian generatif (Gusniwati dan Fatia (2008)).

Selain hubungan antara peubah endogen dan peubah eksogen, matriks korelasi juga menampilkan hubungan antar peubah eksogen. Terdapat tiga pasang peubah eksogen yang memiliki nilai korelasi $\mathrm{r}=1$ yaitu $\left(X_{9}, X_{12}\right) ;\left(X_{10}, X_{13}\right) ;\left(X_{11}\right.$, $\left.X_{14}\right)$. Hal tersebut akan mempengaruhi hasil akhir analisis lintas yaitu kesalahan pendugaan hubungan antar peubahnya (peubah eksogen yang seharusnya berpengaruh signifikan terhadap peubah endogen, bisa saja terdeteksi menjadi tidak berpengaruh secara signifikan), sehingga harus dipilih satu peubah eksogen dari setiap pasangan. Peubah yang dipilih adalah peubah yang lebih mudah diukur yaitu umur keluar bunga jantan $\left(X_{9}\right)$, umur keluar bunga betina $\left(X_{10}\right)$, dan umur masak $\left(X_{11}\right)$. Tiga peubah lainnya tidak diikutsertakan dalam analisis berikutnya.

Ukuran selanjutnya adalah koefisien keragaman (KK) yang mampu menunjukkan besarnya keragaman dari setiap peubah. Berdasarkan Tabel II, jumlah daun hijau saat panen $\left(X_{16}\right)$ memiliki nilai KK tertinggi yaitu sebesar $33,16 \%$ hal tersebut menunjukkan bahwa $X_{16}$ merupakan peubah eksogen yang paling beragam. Sedangkan jumlah baris $\left(X_{3}\right)$ merupakan peubah eksogen yang paling seragam dengan nilai KK sebesar 9,82\%. Jumlah baris pada setiap tongkol berkisar antara 9-14 baris.

Sifat data juga dapat diketahui melalui histogram distribusi frekuensi data (Gambar 2 dan Gambar 3). Data pada setiap peubah dikelompokkan berdasarkan 5 selang seperti yang sudah disebutkan pada sub bab Metode. Panjang tongkol $\left(X_{1}\right)$, jumlah biji per tongkol $\left(X_{4}\right)$, berat biji per tongkol $\left(X_{5}\right)$, berat tongkol $\left(X_{6}\right)$, berat 200 biji $\left(X_{7}\right)$, laju pengisian biji $\left(X_{8}\right)$, umur keluar bunga jantan $\left(X_{9}\right)$, umur keluar bunga betina $\left(X_{10}\right)$, tinggi tanaman $\left(X_{15}\right)$, jumlah daun hijau saat panen $\left(X_{16}\right)$, tinggi keberadaan tongkol $\left(X_{18}\right)$, luas daun $\left(X_{19}\right)$, dan efisiensi 
Tabel II

NILAI KOEFISIEN KERAGAMAN (KK) SETIAP PEUBAH

\begin{tabular}{llll}
\hline Peubah & KK & Peubah & KK \\
\hline X1 & 18.69 & X11 & 10.38 \\
X2 & 9.98 & X12 & 12.15 \\
X3 & 9.82 & X13 & 12.47 \\
X4 & 19.50 & X14 & 10.06 \\
X5 & 19.95 & X15 & 19.54 \\
X6 & 19.72 & X16 & 33.16 \\
X7 & 18.68 & X17 & 13.28 \\
X8 & 23,04 & X18 & 29.11 \\
X9 & 12.65 & X19 & 28.68 \\
X10 & 13.00 & X20 & 22.42 \\
\hline
\end{tabular}

daun $\left(X_{20}\right)$ memiliki pola sebaran yang cenderung simetris. Sehingga dapat disimpulkan data pada 13 peubah tersebut lebih banyak mengumpul di sekitar nilai tengahnya. Peubah diameter tongkol $\left(X_{2}\right)$, umur masak $\left(X_{11}\right)$, dan jumlah daun hijau saat pembungaan $\left(X_{17}\right)$ memiliki pola menjulur ke kiri yang artinya nilai tengah umur masak lebih rendah dari modus datanya. Sedangkan jumlah baris $\left(X_{3}\right)$ memiliki pola sebaran menjulur ke kanan yang artinya nilai tengah laju pengisian biji lebih tinggi dari modus datanya.

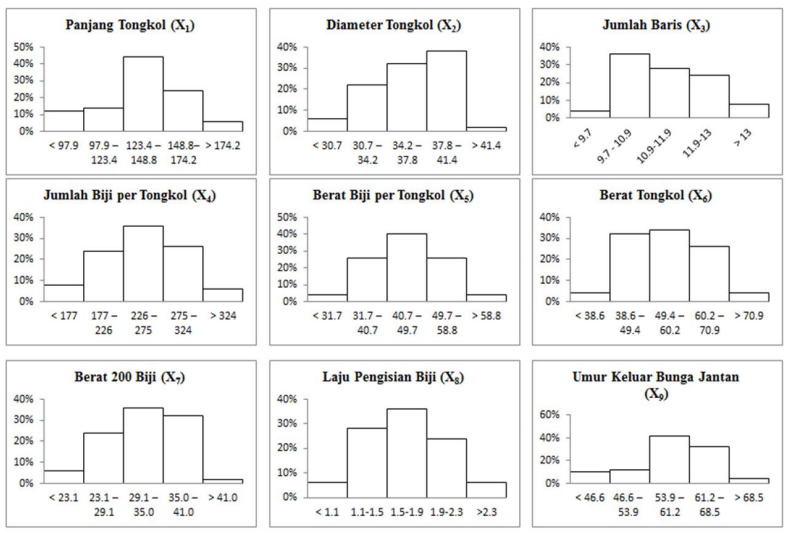

Gambar 2. Histogram distribusi frekuensi data peubah $X_{1}-X_{9}$

\section{B. Analisis Lintas}

Tanaman jagung (Zea mays L.) memiliki peran penting bagi kehidupan, bijinya dimanfaatkan sebagai bahan pangan dan biomassanya dimanfaatkan sebagai bahan pakan. Berdasarkan manfaat tersebut maka dibentuk dua diagram lintas yaitu diagram lintas untuk hasil akhir berat biji $\left(Y_{1}\right)$ yang berhubungan dengan pemanfaatan untuk bahan pangan serta

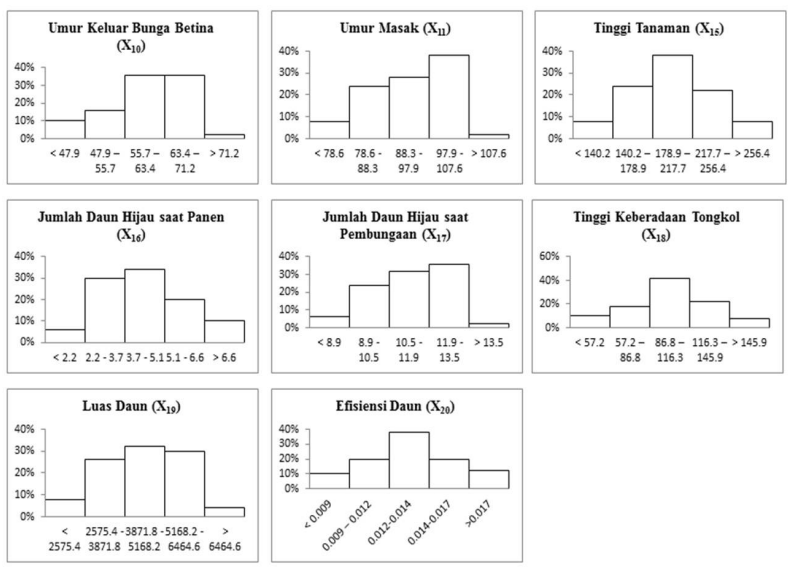

Gambar 3. Histogram distribusi frekuensi data peubah $X_{10}-X_{20}$

industri dan diagram lintas untuk hasil akhir berat brangkasan (biomassa) ( $\left.Y_{2}\right)$ yang berhubungan dengan pemanfaatan untuk bahan pakan serta industri. Model lintas awal tersaji pada bab metodologi di sub bab Model Lintas, model tersebut memberikan luaran yang tidak konvergen atau matriks yang dianalisis merupakan matriks non definit positif. Hal tersebut disebabkan oleh semua peubah eksogen diikutsertakan dalam model, sedangkan berdasarkan hasil statistika deskriptif menunjukkan bahwa terdapat tiga pasang peubah eksogen yang memiliki nilai korelasi $r=1$. Sehingga, model awal tidak dapat lagi digunakan karena memberikan hasil pendugaan hubungan yang tidak tepat.

Model alternatif (Gambar 4) diperlukan untuk mendapatkan hasil pendugaan hubungan antar peubah yang tepat. Oleh karena itu, peneliti merancang hipotesis model baru berdasarkan hasil analisis statistika deskriptif dan tetap memperhatikan skema awal pengelompokkan peubah-peubah eksogen menjadi tiga kelompok yaitu fase pra panen (pembungaan), fase pasca panen, dan hasil akhir. Model alternatif ini tidak memanfaatkan peubah eksogen yang memiliki nilai korelasi $r=1$ terhadap peubah eksogen lainnya yaitu $X_{12}, X_{13}$, dan $X_{14}$. Selain itu model alternatif juga tidak memanfaatkan peubah umur masak $\left(X_{11}\right)$, karena umur masak tanaman jagung tidak berpengaruh terhadap hasil biji maupun biomassanya, melainkan lebih berpengaruh terhadap mutu fisiologisnya (Arief (2004)).

\section{1) Pengujian Asumsi Analisis Lintas:}

a) Asumsi normalitas dan sisaan saling bebas 


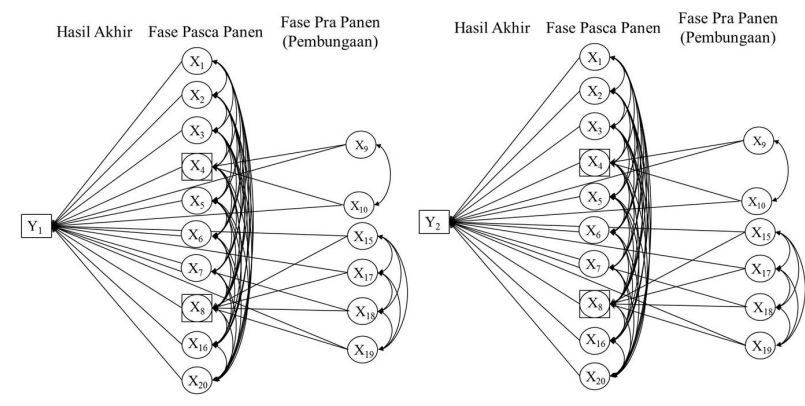

Gambar 4. Diagram lintas model alternatif

i) Hasil uji asumsi normalitas (Tabel III) menunjukkan bahwa data pada persamaan struktural $Y_{1}, Y_{2}, X_{4}$, dan $X_{8}$ berdistribusi normal terbukti dengan nilai signifikansi normalitas lebih besar dari $\alpha=0,05$.

ii) Uji asumsi sisaan saling bebas dapat diketahui dengan melalukan Runs Test pada setiap sisaan hasil regresi linier berganda dari setiap persamaan struktural. Sisaan dikatakan saling bebas apabila nilai signifikansi dari Runs Test lebih besar dari $\alpha=5 \%$. Berdasarkan hasil uji (Tabel III) terlihat bahwa nilai signifikansi dari setiap persamaan struktural lebih besar dari $\alpha$, sehingga dapat diasumsikan bahwa sisaan dari setiap persamaan struktural saling bebas.

Tabel III

DAFTAR PEUBAH YANG DIGUNAKAN

\begin{tabular}{llll}
\hline $\begin{array}{l}\text { Peubah } \\
\text { endogen }\end{array}$ & Peubah eksogen & $\begin{array}{l}\text { Nilai } \\
\text { signifikansi } \\
\text { normalitas }\end{array}$ & $\begin{array}{l}\text { Nilai } \\
\text { signifikansi } \\
\text { Runs Test }\end{array}$ \\
\hline$Y_{1}$ & $X_{1}, X_{2}, X_{3}, X_{4}, X_{5}$, & 0,957 & 0,775 \\
& $X_{6}, X_{7}, X_{8}, X_{16}$, & & \\
$Y_{2}$ & $X_{20}$ & 1,000 \\
& $X_{1}, X_{2}, X_{3}, X_{4}, X_{5}$, & 0,999 \\
$X_{4}$ & $X_{6}, X_{7}, X_{8}, X_{16}$, & \\
$X_{8}$ & $X_{20}$ & 0,948 & 0,086 \\
\hline
\end{tabular}

b) Asumsi linieritas

Linieritas hubungan peubah endogen dan eksogen dapat diketahui melalui uji nilai signifikansi linieritas, hubungan kedua peubah dikatakan linier apabila nilai signifikansi kurang dari $\alpha=5 \%$. Selain itu, linieritas hubun- gan juga dapat diketahui melalui nilai signifikansi simpangan linieritas, hubungan kedua peubah dikatakan linier apabila nilai signifikansi lebih dari $\alpha=5 \%$. Hasil uji linieritas menyatakan bahwa hampir semua peubah eksogen pada persamaan struktural $Y_{1}$ memiliki hubungan linier terhadap $Y_{1}$ terbukti dengan nilai signifikansi linieritas yang kurang dari $\alpha$. Peubah $X_{16}$ memiliki nilai signifikansi linieritas sebesar $0,465>\alpha$, tetapi peubah $X_{16}$ dapat diasumsikan memiliki hubungan linier dengan $Y_{1}$ karena nilai signifikansi simpangan linieritasnya $>\alpha$. Hal serupa juga terjadi pada persamaan struktural $Y_{2}$. Sedangkan pada persamaan struktural $X_{4}$ dan $X_{8}$ semua peubah eksogen memiliki hubungan yang linier terhadap peubah endogennya, dibuktikan dengan nilai signifikansi linieritasnya $<\alpha$.

c) Asumsi hubungan aditif dan kausal satu arah (rekursif)

Asumsi keaditifan hubungan terpenuhi pada keempat persamaan struktural karena persamaan tersebut menujukkan bahwa peubah endogen merupakan hasil penjumlahan dari pengaruh langsung peubah eksogen dan pengaruh sisaan. Sedangkan hubungan kausal satu arah dapat dilihat pada diagram lintas model alternatif (Gambar 4), dalam diagram tersebut terdapat simbol garis lurus dengan anak panah satu arah. Simbol tersebut berarti adanya hubungan antara peubah di pangkal garis (peubah eksogen) dengan peubah di ujung garis (peubah endogen), jadi hubungan yang terjadi adalah peubah eksogen mempengaruhi peubah endogen tidak berlaku sebaliknya.

2) Berat Biji per 60 Tongkol $\left(Y_{1}\right)$ : Persamaan struktural dari model lintas untuk berat biji $\left(Y_{1}\right)$ adalah sebagai berikut :

$$
\begin{array}{r}
Y_{1}=0,015 X_{1}-0,065 X_{2}+0,005 X_{3}+0,081 X_{4}- \\
0,085 X_{5}+0,054 X_{6}+0,222 X_{7}+0,401 X_{8}+ \\
\quad 0,120 X_{9}-0,304 X_{10}-0,185 X_{15}-0,008 X_{16} \\
+0,206 X_{17}+0,143 X_{18}+0,447 X_{19}+0,364 X_{20} \\
X_{4}=0,154 X_{9}+0,355 X_{10} \\
X_{8}=0,816 X_{15}+0,408 X_{17}-1,006 X_{18}+0,373 X_{19}
\end{array}
$$

Berdasarkan persamaan struktural dan diagram 


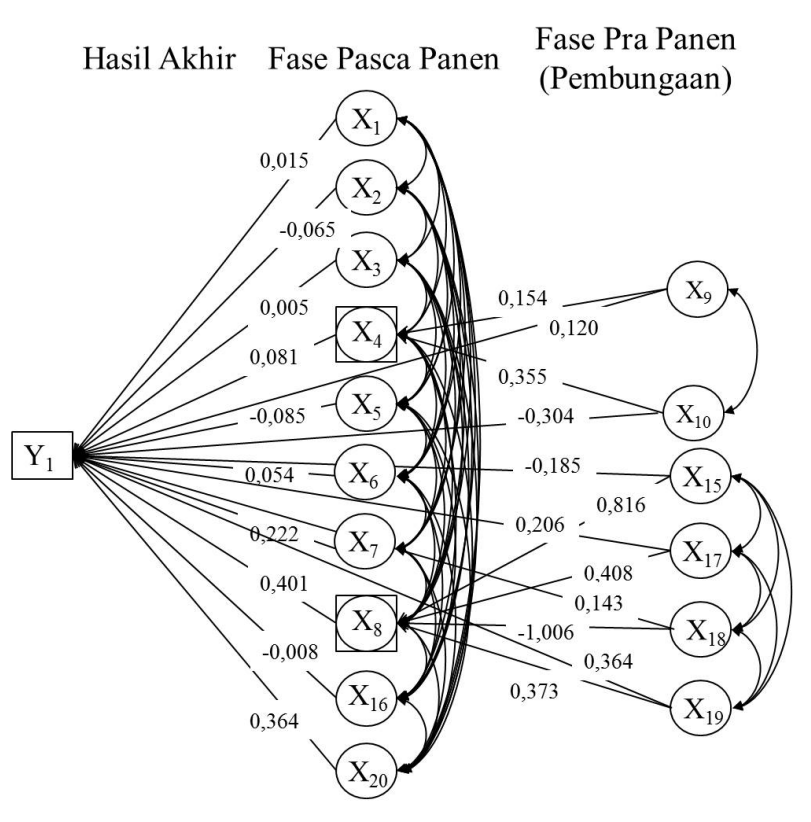

Gambar 5. Diagram lintas untuk berat biji $\left(Y_{1}\right)$

lintas (Gambar 5) terlihat bahwa luas daun $\left(X_{19}\right)$ memiliki pengaruh langsung terbesar dan positif terhadap berat biji $\left(Y_{1}\right)$ yaitu sebesar 0,447 . Hal ini menunjukkan apabila peubah lain dianggap konstan maka setiap kenaikan satu satuan luas daun akan meningkatkan berat biji sebesar 0,447. Luas daun $\left(X_{19}\right)$ merupakan sifat morfo-agronomis tanaman jagung. Sedangkan sifat yang memiliki pengaruh langsung negatif terbesar merupakan sifat fisiologis tanaman jagung yaitu umur keluar bunga betina $\left(X_{10}\right)$ dengan pengaruh sebesar -0,304. Sifat yang memberikan pengaruh tidak langsung terbesar dan positif terhadap $Y_{1}$ melalui jumlah biji per tongkol $\left(X_{4}\right)$ yaitu umur keluar bunga betina $\left(X_{10}\right)$ yang merupakan sifat fisiologis tanaman jagung dengan pengaruh sebesar 0,355 . Sementara itu, dengan pengaruh tidak langsung terbesar terhadap $Y_{1}$ melalui $X_{8}$ adalah tinggi tanaman $\left(X_{15}\right)$ yang merupakan sifat morfo-agronomis tanaman jagung dengan pengaruh sebesar 0,816 .

Total keragaman data yang dapat dijelaskan oleh model untuk berat biji $\left(Y_{1}\right)$ diukur dengan koefisien determinasi umum $\left(R_{m}^{2}\right)=1-\left(1-R_{Y_{1}}^{2}\right)\left(1-R_{X_{4}}^{2}\right)(1$ - $\left.R_{X_{8}}^{2}\right)=99,1 \%$. Hal ini menunjukkan bahwa model analisis lintas mampu menjelaskan data sebesar $99,1 \%$, sedangkan sisanya $0,9 \%$ dijelaskan oleh peubah lain di luar model. Nilai Goodness of Fit
Index (GFI) dari model untuk berat biji $\left(Y_{1}\right)$ berada pada selang 0,80 - 0,90 yaitu sebesar 0,834 sehingga dapat disimpulkan model ini baik (marginal fit) (Riadi (2013)).

3) Berat Brangkasan (Biomassa) ( $\left.Y_{2}\right)$ : Persamaan struktural dari model lintas untuk berat brangkasan (biomassa) $\left(Y_{2}\right)$ adalah sebagai berikut :

$$
\begin{array}{r}
Y_{2}=0,388 X_{1}+0,162 X_{2}+0,185 X_{3}-0,235 X_{4}+ \\
0,384 X_{5}-0,284 X_{6}-0,106 X_{7}-0,134 X_{8}- \\
0,366 X_{9}+0,502 X_{10}-0,017 X_{15}+0,026 X_{16} \\
-0,140 X_{17}+0,343 X_{18}+0,454 X_{19}+0,065 X_{20}
\end{array}
$$

$X_{4}=0,154 X_{9}+0,355 X_{10}$

$X_{8}=0,816 X_{15}+0,408 X_{17}-1,006 X_{18}+0,373 X_{19}$

Berdasarkan diagram lintas (Gambar 6) dan persamaan struktural terlihat bahwa umur keluar bunga betina $\left(X_{10}\right)$ memiliki pengaruh langsung terbesar dan positif terhadap berat brangkasan $\left(Y_{2}\right)$ yaitu sebesar 0,502. Hal ini menunjukkan apabila peubah lain dianggap konstan maka setiap kenaikan satu satuan umur keluar bunga betina akan meningkatkan berat brangkasan jagung sebesar 0,502. Umur keluar bunga betina $\left(X_{10}\right)$ merupakan sifat fisiologis tanaman jagung. Sedangkan sifat yang memiliki pengaruh langsung negatif terbesar merupakan sifat fisiologis tanaman jagung yaitu umur keluar bunga jantan $\left(X_{9}\right)$ dengan pengaruh sebesar -0,366. Sifat yang memberikan pengaruh tidak langsung terbesar dan positif terhadap $Y_{2}$ melalui jumlah biji per tongkol $\left(X_{4}\right)$ yaitu umur keluar bunga betina $\left(X_{10}\right)$ yang merupakan sifat fisiologis tanaman jagung dengan pengaruh sebesar 0,355. Sementara itu, dengan pengaruh tidak langsung terbesar terhadap $Y_{2}$ melalui laju pengisian biji $\left(X_{8}\right)$ adalah tinggi tanaman $\left(X_{15}\right)$ yang merupakan sifat morfo-agronomis tanaman jagung dengan pengaruh sebesar 0,816.

Total keragaman data yang dapat dijelaskan oleh model untuk berat brangkasan $\left(Y_{2}\right)$ diukur dengan koefisien determinasi umum $\left(R_{m}^{2}\right)=1-\left(1-R_{Y_{1}}^{2}\right)(1$ - $\left.R_{X_{4}}^{2}\right)\left(1-R_{X_{8}}^{2}\right)=96,4 \%$. Hal ini menunjukkan bahwa model analisis lintas mampu menjelaskan data sebesar 96,4\%, sedangkan sisanya 3,6\% dijelaskan oleh peubah lain di luar model. Nilai Goodness of Fit Index (GFI) dari model untuk berat brangkasan $\left(Y_{2}\right)$ berada pada selang 0,80 - 0,90 yaitu sebesar 0,834 sehingga dapat disimpulkan model ini 


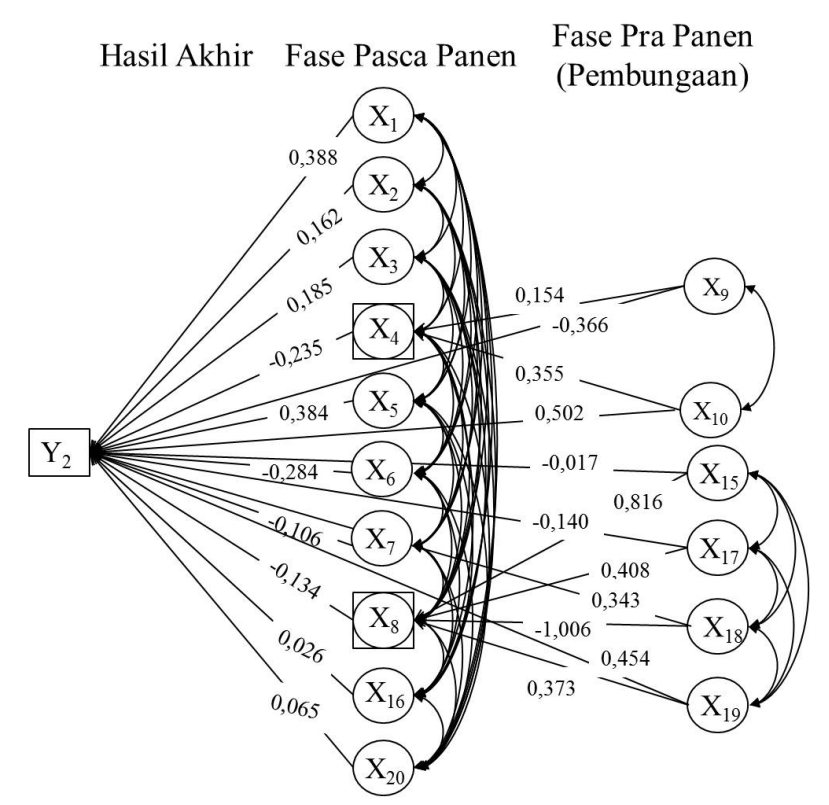

Gambar 6. Diagram lintas untuk berat brangkasan (biomassa) $\left(Y_{2}\right)$

baik (marginal fit) (Riadi (2013)).

Peubah endogen berat biji $\left(Y_{1}\right)$ dan berat brangkasan (biomassa) $\left(Y_{2}\right)$ memiliki nilai korelasi yang cukup besar yaitu $r=0,627$. Tetapi berat biji dan berat brangkasan memiliki ciri khas masingmasing. Pada penelitian ini berat biji $\left(Y_{1}\right)$ merupakan komponen jagung yang difokuskan untuk pemanfaatan sebagai bahan pangan dan industri. Sementara itu berat brangkasan $\left(Y_{2}\right)$ difokuskan untuk pemanfaatan sebagai bahan pakan dan industri.

\section{Simpulan}

Berdasarkan hasil analisis lintas pada penelitian ini dapat disimpulkan bahwa kriteria seleksi yang efektif untuk meningkatkan berat biji jagung secara langsung adalah luas daun. Sedangkan kriteria seleksi yang efektif untuk meningkatkan berat brangkasan jagung secara langsung adalah umur keluar bunga betina. Sementara kriteria seleksi yang efektif untuk meningkatkan berat biji dan berat brangkasan jagung secara tidak langsung adalah tinggi tanaman melalui laju pengisian biji. Ketiga sifat tersebut merupakan sifat-sifat yang dapat diamati pada fase pra panen (pembungaan dan pengisian biji), hal ini dapat mempermudah para pemulia tanaman untuk melakukan seleksi jagung unggul sejak dini.

\section{DAFTAR PUSTAKA}

Arief, R dan Syamuun, S. d. S. S. (2004). Evaluasi mutu fisik dan fisiologi benih jagung cv. lamuru dari ukuran biji dan umur simpan yang berbeda. Sains dan Teknologi 2, 54-64.

Asadi dan Woerjono, M dan Jumanto, H. (2004). Keefektifan metode seleksi modifikasi bulk dan pedigri untuk karakter agronomi dan ketahanan terhadap virus kerdil (ssv) galur-galur f7 kedelai. Zuriat 15 1, 64-76.

Dillon, W. R. and M. Goldstein (1984). Multivariate Analysis Methods and Applications. New York: John Wiley \& Sons.

Gusniwati dan Fatia, N M E dan Arief, R. (2008). Pertumbuhan dan hasil tanaman jagung dengan pemberian kompos alang-alang. Agronomi 12, 26.

Indriantoro, N dan Bambang, S. (2002). Metodologi Penelitian Bisnis. Yogyakarta: BPFE.

Purwono dan Hartono, R. (2008). Bertanam Jagung Unggul. Jakarta: Penebar Swadaya.

Rahmawati, D. (2012). Analisis lintas terhadap sifat agronomis tanaman jagung (Zea mays 1.). Master's thesis, Institut Pertanian Bogor.

Riadi, E. (2013). Aplikasi Lisrel untuk Penelitian Analisis Lintas. Yogyakarta: Penerbit Andi.

Suprapto (2005). Bertanam Jagung. Jakarta: Penebar Swadaya. 